\title{
An analysis on the advancement of technologies and the presence of technological resources in teaching practice
}

\author{
Maria José de Lima Silva Andrade'; Katia Regina Orlando da Silva²; Maria Solange dos Santos \\ Gama $^{3}$; Teresa Amelia Barros de Souza ${ }^{4}$; Emanuella Barros de Souza Oliveira Álvares*5
}

1 Specialist in Educational Management

2 Specialist in Informatics and Education

3 Mathematics Specialist.

4 Professor of the Academic Center of Vitória de Santo Antão - UNIVISA

5 Professor at the Academic Center of Vitória de Santo Antão - UNIVISA.

E-mail adresses: mlimaandrade2011@bol.com.br (Maria José de Lima Silva Andrade), katiarosilva@gmail.com (Katia Regina Orlando da Silva), solgama23@gmail.com (Maria Solange dos Santos Gama), teresa.amelia@hotmail.com (Teresa Amelia Barros de Souza) emanuelabarros@univisa.edu.br (Emanuella Barros de Souza Oliveira Álvares).

${ }^{*}$ Corresponding author

\section{To cite this article:}

Andrade, M.J.L.S.; Silva, K.R.O.; Gama, M.S.S.; Souza, T.A.B.; Álvares, E.B.S.O. An analysis on the advancement of technologies and the presence of technological resources in teaching practice. International Journal of Sciences. Vol. 2, No. 2, 2021, pp. 01-04. ISSN 27635392 .

Received: 07 27, 2021; Accepted: 07 28, 2021; Published: 09 06, 2021

\begin{abstract}
Living in the 21st century, where Information and Communication Technologies, ICT, advance and become increasingly present in our daily life, it is expected that its use will extend to teaching practice and bring significant benefits in the teaching and learning process. In this article we have as objectives: to analyze the advancement of technologies; identify the main technological tools currently used by teachers in their pedagogical practice; to reflect on possible contributions that its use brings to the teaching and learning process and to point out the possible difficulties faced that still prevent its more effective use. For the formulation of this article, we initially used bibliographic research to give us a basis and then an online research, with teachers, regarding the use of technological resources in the classroom. As a theoretical contribution we use studies by authors such as Bruzzi (2016), Skinner (1972), Valente (1995), among others. We conclude, with this work, that the use of digital technologies in teaching practice exists yes, however several factors corroborate for its use to represent an improvement in the teaching and learning process. The use is conditioned to various factors such as equipment (hardware), software, teacher training, management, among others. The union of these elements or the lack of one of them makes success or not success happen. This leads us to a constant challenge of appropriating ICT in order to promote a quality education, which motivates people involved in the teaching and learning process to seek and participate in the construction of new knowledge.
\end{abstract}

Keywords: Education, Technology, Technological Resources, Teaching Practice.

\section{Introduction}

We live with technology in such a natural way, that sometimes we do not realize how indispensable it already becomes in everyday activities. However, in the area of education we noticed that there have always been discussions and questions regarding the advances and applicability of this technology in the classroom. We observe that technologies have transformed the habits of society and, of course, these changes have arrived in schools. That is why it is indispensable to analyze what changes are actually happening. We realize that technologies are not only the product of the consumer market, but are products of social practices, hence their relevance.

When analyzing the evolution of technology, we will see that it has always been present in some way in the educational field, so it is not something so new and extraordinary, and although we have access to this equipment, there is still a lot of talk about improving and promoting quality education. This leads us to affirm that the presence of technological resources and equipment does not guarantee the success of teaching and learning. This issue requires a broader look at us. 
According to Bruzzi (2016) education has been working with technology since 1650 . Starting with the use of teaching artifacts such as Horn-Book, Ferule, followed by pencil, blackboard / white, calculator, among others until we reach the digital technologies, of which we make use today.

It is common for ICT to advance to bring some discomfort to those who, despite living with them, do not yet understand or use it effectively. We cannot also rule out the difficulties faced by many teaching professionals, such as: lack of physical structure, overcrowding of classrooms, low salaries, lack of training, and others. These factors, in fact, hinder learning and prevent students from performing well. Inserting technological resources from this scenario is not an easy task, but we cannot say that it is impossible. We still have many good examples of teachers who seek to develop creative ways to teach and educate, even in the face of so many limitations. We should take as a basis Article 32, item II of the LDB (Law of Guidelines and Bases 9394/96), which points out as objective of the basic formation of the citizen the understanding of the natural and social environment, the political system, technology, arts and values on which society is based.

Within this perspective, we believe that it is extremely relevant that there is a greater reflection on the theme addressed in this article that aims to analyze the advancement of technologies and their effective applicability in the classroom. In addition, we try to identify the main technological tools currently used by teachers in their pedagogical practice and, finally, point out the possible difficulties that still prevent the presence of technologies in the classroom, with the objective of promoting an improvement in the teaching and learning process.

\section{Development}

PCN define Technological Resources as technology products or objects created to facilitate human work and ICT, as technological resources that allow the transit of information. With the advance of ICT, there have also been many guidelines on how to use it in teaching and learning environments. Also, according to (PCN - 2005) "ICT, in addition to being information vehicles, enable new forms of ordering human experience... in addition to enabling new forms of communication, it generates new ways of producing knowledge." For the NPs, "the incorporation of technological innovations only makes sense if it contributes to the improvement of the quality of education. The mere presence of new technologies in the school is not, in itself, a guarantee of higher quality in education." There are some challenges that must be faced by teachers in so that the use of ICT promotes significant changes in the quality of learning teaching. There needs to be planning and adaptation to the learning goal that is intended to be achieved.

\subsection{From the last century to the information society, the evolution of technology in education.}

That digital technologies are in our lives is fact, but it didn't happen overnight. This technological development has been going on for some time and in education we observe that it has been happening since the beginning of the 20th century.

This evolution has changed our lives, as well as our way of teaching. The available technologies were not always digital, however education always used the resources of the time, in order to help the development of knowledge, as it was with the radio in 1925. "Since radio I consider (a personal idea), that the school was already in the era of technological modernity", Bruzzi's account, (2016, p3). Initially they were basically used to maintain the communication of ships with those who were on the ground, and during the war it was also widely used to send messages.

From radio to here, until the 21 st century, a lot has come again in the age of technology. We go through television, Skinner's teaching machines, $L O G O$ language, the arrival of www (World Wide Web), the internet 2.0, individual computers, smartphones with access to WIFI among others.

Great were the transformations that have occurred from there to today, to the point of being called the information society. About this (Coll, 2011, p17) tells us:

Among all the technologies created by human beings, those related to the ability to represent and transmit information, that is, information and communication technologies are of special importance, because they affect the day-to-day life of students and teachers. We live in a time when ICT goes beyond the common basis of content. (Apud Bruzzi, 2016, p2) and these changes related to information age technologies also imply the way we teach our students. We must encourage them to become critical, reflective students always in search of the new.

\subsection{Using technology significantly in the learning teaching process.}

It is known that technology is present in our daily lives so that we cannot ignore the fact that it has become much more than a support, becoming part of the culture of society, that is, technology has changed people's habits and customs and in the face of these transformations it is necessary that teachers also change their posture in classrooms, since everyone has access to some kind of technology. It is necessary to use these resources in favor of a teaching that instills in student's curiosity and interest in knowledge. According to Valente (1995, p. 41) education can no longer be based on the instruction in which the teacher passes to the student, but on the construction of knowledge by the student and on the development of skills such as learning to seek information, understanding it and knowing how to use it in problem solving.

Technological resources are everywhere, and have not been created to make life difficult for anyone, but we know that it is not an easy task for teachers to offer quality education regardless of technological resources since the 
success of teaching is not restricted to the use of these tools.

As Paulo Freire quoted: "teaching is not transferring knowledge, but creating the possibilities for its production or construction" (Freire, 2011, p. 24).

Currently, among so many technological resources we can highlight the computer and the internet as one of the main resources in which we can and should explore in a very significant way in the classrooms, this when it is possible to access them. Although we live in a technological society, many schools and places live in precariousness, which also does not prevent them from thinking of an education that promotes the autonomy of students, according to the local reality, but always seeking new possibilities.

However, with regard to the use of the computer and internet we have infinite possibilities of interaction and between these possibilities, the exchange of information and construction of various knowledge, all this in a very fast and random way. It is necessary, therefore, that the teaching professional has clear objectives for each class proposed through development of projects in which the computer is used as a source of information and resolutions of problems that make social significance for students, thus emphasizing the importance of Doing and Understanding, presented by Piaget (1978). The author also notes that the passage of knowing how to understand it is due to the awareness, which consists in the transformation of the scheme of actions (which allow doing so) into meanings and operations (which constitute conceptualization). Apud (Valente, 1995, p. 42) and it is precisely this awareness that will cause the student to go beyond the level to make the level understand through the interaction and reflection of the use of this equipment. Thus, it is expected that the teacher appropriates these challenges and understands that this knowledge must also be constructed by him, to the extent that he is able to make use of these resources proposing to be a facilitator of the student's learning process.

\section{Methodology}

In our research we seek to investigate how technological resources are being used in the classroom, what are the main resources used, how often these resources are present in teaching practice, as well as what are the main difficulties faced by teachers that prevent their use.

To do this, we prepared an online questionnaire in google forms, which included the following questions:

1. What is your age group?

2. Sex.

3. How long have you been working as a teacher?

4. Do you teach at what type of institution?

5. What level of education do you work for?

6. In your undergraduate course did you have any discipline that addressed the use of technological resources in teaching practice?

7. Among the technological resources below, whathave you used in your teaching practice? (the options for this question were as indicated below:)
- Television

- Radio

- Computer

- Internet

- Overhead projector

- Digital Slate

- Educational software

- Apps

- Social networks

- Digital videos

8. In the school you teach students and teachers have access to some internet network?

9. On a scale of 0 (zero) to 10 (ten) rate the importance you think of using some technological resource in your classes

10. Do you often use any technological resource in your teaching practice how often?

11. Are you encouraged to use technological resources in the school where you teach?

12. Does the school you teach at have a computer lab?

13. How is the computer lab used in the school where you teach?

14. What are the main difficulties that can prevent the use of technological resources in your classes?

15. How do you evaluate your computer skills?

16. What is the usefulness of using the computer in your teaching practice?

- Surf the internet.

- Do internet search.

- Chat on the internet.

- Read and reply to emails.

- Type texts.

- Use programs specific to your work.

- Prepare classes.

- Play.

All the questions contemplated in this questionnaire were elaborated with the objective of basing our research and what we intended to investigate.

\section{Results}

According to the answers to the questionnaire, we initially identified some characteristics of the teachers who participated in the research:

- most are female (approximately $74 \%$ );

- are over 30 years of age (approximately $82 \%$ ); and

- more than half $(55 \%)$ has been working in the teaching area for more than 10 years, and of these people, specifically, $38 \%$ have been teaching for more than 15 years.

These data reveal that the people who answered the questionnaire are women with significant experience in the area of teaching.

In relation to the institutions where they teach and the modality of education in which they operate:

- Most are from the public network, $47 \%$ of the municipal network, approximately $27 \%$ of the state 
4 Andrade, M.J.L.S.; Silva, K.R.O.; Gama, M.S.S.; Souza, T.A.B.; Alvares, E.B.S.O. An analysis on the advancement of technologies and the presence of technological resources in teaching practice ...

network and the other are from the private network.

- Almost all work in basic education (approximately $91 \%)$ and the other in higher education.

More than half of the professor's report that they had no discipline during their graduation that addressed the use of technological resources, although most already make use of them in their classes. The most used by them is the computer, followed by Data show and television, as graphic provided by google forms, presented below:

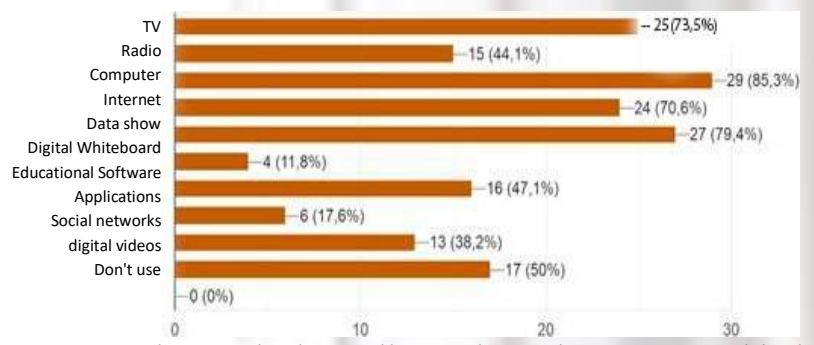

We observed that all teachers have some kind of knowledge in computer science: half of them consider their knowledge sufficient for most applications, $41 \%$ consider that they know the basics of information technology and the others think they have advanced knowledge.

Regarding the use of technological resources, slightly more than half (53\%) classify them as important; a significant portion (approximately 62\%) are encouraged to use them and approximately $53 \%$ make use of them in their teaching practice at least once a week.

It was also found that approximately $62 \%$ of the schools they teach make available internet to students and teachers. Despite this, only slightly more than half of the schools have a computer laboratory (53\%) and these laboratories are still underutilized, as only $45 \%$ of them are frequented by students and teachers.

As the computer was the technological resource pointed out as the most used by teachers, we indicate in the graph below what they answered in relation to the purpose for which they use this resource to assist in their daily practices.

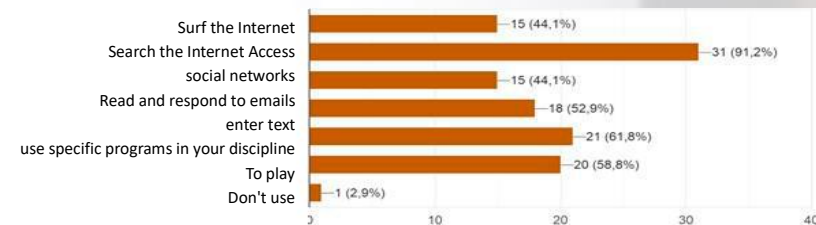

We observed that the computer is still widely used to do research on the Internet, although we found that not all those who answered the questionnaire have access to the Internet in their educational institutions.

\section{Conclusions}

We can conclude that the advancement of technology and the presence of technological resources in our daily lives have brought to our society many possibilities of development in the most diverse areas of knowledge. We observed, however, that the development of the teaching and learning area does not go in the same proportion as technological advances.

We found that digital inclusion policies have emerged since the mid-1990s and the creation of several projects such as PROINFO, "Rede Jovem" Program, Electronic Government Program, Connected Citizen Project, One Computer per Student, among others, whose objective was to bring the Internet to educational institutions in both the urban and rural areas (Brazil). Court of Auditors of the Union. Public policy of digital inclusion), did not achieve its initial objectives proposed by the Federal Government. A proof of this is what we found in our research, where there are still schools that do not make internet available to their students and teachers. Although, according to Valente (1995), the presence of the Internet does not guarantee the construction of knowledge, these factors do not favor the full use of technological resources that could contribute to improving the quality of education. Also, according to Valente (1995), the Internet represents the greatest potential for ICTs application.

The questionnaire we applied in our research was answered by 35 teachers and we observed that the greatest difficulty still faced by them is the lack of physical structure (50\% of them stated this), although most of them recognize that it is important to use technological resources in their classrooms and all have computer skills ranging from basic to advanced.

We also observed, with our research, that using technological resources exploring all their potential is not to replace teaching resources - leaving the blackboard to the computer. It is necessary that the techniques and methods used, through these resources, are in accordance with the planning, procedures and teaching objectives that are intended to be achieved.

\section{References}

[1] BRASIL. Lei de Diretrizes e Bases da Educação Nacional, Lei $\mathrm{n}^{\circ}$ 9394, 20 de dezembro de 1996.

[2] BRASIL. Parâmetros Curriculares Nacionais.Ano 2000. Disponível em:

http://portal.mec.gov.br/seb/arquivos/pdf/14_24.pdf. Acessado em 02 de janeiro de 2019.

[3] BRASIL. Política Pública de Inclusão Digital. Tribunal de Contas da União - Brasília: TCU, Seinfraaerotelecom. Ano 2015.

[4] BRUZZI, Demerval Guilarducci. Uso da tecnologia na educação, da história à realidade atual.: Revista Polyphonia, v. 27/1, jan./ jun. 2016.

[5] COLL, C. O Construtivismo na Sala de Aula. Ática, São Paulo,2011. 
[6] FREIRE, Paulo Pedagogia da Autonomia: Saberes Necessários à Prática Educativa. São Paulo: Pax e Terra, 2011.

[7] PIAGET, J. (1978). Fazer e compreender. São Paulo: Melhoramentos; Edusp.1978.

[8] SKINNER, Burrhus Frederic. Tecnologias do Ensino. São Paulo: Editora da Universidade de São Paulo, 1972.

[9] VALENTE, José Armando. Informática na Educação: conformar ou transformar a escola. In: PERSPECTIVA. Florianópolis, UFSC/CED, NUP, n. 24 p. 41 - 49, 1995. 